\title{
CEO Compensation from M\&As in Australia
}

Paper Date: 1 February 2010

\begin{abstract}
This paper investigates the extent to which Australian CEOs are compensated following the completion of mergers and acquisitions $(\mathrm{M} \& \mathrm{~A})$ with reference to the incentive alignment and managerial power perspective. Findings reveal that CEOs of acquiring firms receive significantly higher compensation in the year of completing M\&As and one year after. This higher compensation is presented in all forms: bonus only, salary only, salary and bonus, and total compensation. It is also found that the incentive alignment and managerial power approach are not mutually exclusive and they both can have some degrees of explaining the variation of CEO compensation following mergers. We find a positive correlation between CEO compensation and firm performance, and some measures of CEO's effort and skill in completing the deal. However, we observe that CEOs of bidding firms have significantly lower bonus and total compensation if there is any entrenchment in the CEO governance process (i.e. CEO is also a chair of the board, or a member of the nominating committee). This result is sharply opposite to the US evidence (Gristein and Hribar (2004)) where CEO compensation after mergers is significantly driven by CEO power. Overall our findings are more consistent with the predictions of the incentive alignment theory rather than the managerial power theory.
\end{abstract}

Keywords: Mergers and acquisitions; CEO compensation; Managerial power; Incentive alignment; Firm performance.

JEL classification: G34, J33 


\section{Introduction}

In May 2005, Macquarie Bank Ltd unveiled a record annual profit for the financial year ending 31st March 2005 with after-tax profit from ordinary activities being $\$ 852$ million, up from $\$ 521$ million the previous financial year, representing an increase of $64 \%{ }^{1}$ However, the attention of media and politicians ${ }^{2}$ was not on its soaring profit, but on its lucrative remuneration packages to executives. The bank's CEO, Allan Moss, received total remuneration of $\$ 18.6$ million during 2004-2005 financial year with cash bonus of $\$ 12.3$ million, up from his total remuneration of $\$ 12.3$ million and bonus of $\$ 8.1$ million in the previous financial year. It was also noted that Macquarie completed several acquisitions during the 2004-2005 financial year. ${ }^{3}$ Previous US and UK literature show that acquiring firms make once-off bonus payments to their CEOs for M\&A completion (Gristein and Hribar (2004), Coakley and Iliopoulou (2006)). This has thus prompted our interest about the extent to which mergers and acquisitions (M\&As) can influence CEO remuneration in the Australian context.

There are two different views on CEO compensation. The traditional view (or incentive alignment) claims that CEOs should be rewarded for their skill, effort and company performance, and the executive compensation package should be designed in a way to align managers' interests with those of shareholders (e.g. Jensen and Meckling (1976), Haugen and Senbet (1981)). In contrast, the managerial power approach (or rent extraction) argues that executives can use their power to influence their compensation arrangements and to extract rent (e.g. Core et al. (1999), Bebchuk et al. (2002)). A study in the US market by Gristein and Hribar (2004) generally concludes that the increased bonus after acquisition is driven more by CEO power, and less by the effort in completing the bid, or the maximisation of shareholder wealth. Therefore, our main research question is to explore whether their findings are also replicated in Australia, given Australia is a smaller capital market and has different corporate governance arrangements to the US.

The main contributions of this study to the existing Australian literature are three-fold. To our best knowledge, this paper is the first Australian work examining executive compensation of

\footnotetext{
${ }^{1}$ Macquarie Bank Ltd 2005 Financial Report.

${ }^{2}$ Treasurer Peter Costello criticized into the sheer size of the bank's pay packages and said it was "beyond comprehensive for most people", and "I cannot understand how one person can be worth $\$ 18$ million" ("Fed: Govt/Labour rounds on Macquarie payouts", AAP General News Wire, 18th May 2005).

${ }^{3}$ For example, significant acquisitions that Macquarie undertook over the financial year 2004-2005 was to buy 92 radio stations in 45 Australian regional markets, and to form Macquirie Goodman Manangement (MGQ), Australian's largest industrial property group, from a merger between Macquarie Goodman Industrial Trust and Macquarie Goddman Management Limited (Macquarie Bank Limited 2005 Annual Review). It also made acquisitions to other ASX-listed companies such as RG Capital Radio Ltd (100\%) and RP Data Ltd (50\%) (Source: SDC database).
} 
acquiring firms after the completion of M\&As. Although past research on executive compensation in Australia has investigated the relationship between executive pay, labour demand and corporate governance (e.g. Fleming and Stellios (2002), Chalmers et al. (2006)), their focus is mainly on all ASX-listed firms. Given M\&As is one of the most significant investment decisions that CEOs make, it is worthwhile to study the practice of remunerating CEOs in a subset of acquiring firms. Secondly, the Federal Government's Corporate Law and Economic Reform Program (CLERP), Paper No.3 states that corporate governance practices by Australian companies should be continuously monitored by the Australian Stock Exchange and relevant industries and professional bodies. Our research will thus contribute towards this monitoring. The third contribution of this paper is that we perform our analysis with an uniquely hand-collected dataset, spanning over 8 years from 2000 to $2007 .{ }^{4}$ Although Section 300A(1) of the Corporations Act has enhanced the CEO compensation disclosure regime from 1st July 1998, the existence of an electronic database on remuneration and corporate governance data in Australia is very limited. ${ }^{5}$

We start our analysis by examining the effect of M\&As on CEO compensation over the whole Boardroom Connect4 database over the period 2000 to 2007 with 4,002 firm-year observations. Our results suggest that CEO compensation is significantly increased in the year of M\&A completion and even one year after. This finding is upheld for all types of CEO compensation (bonus only, salary only, salary and bonus, and total compensation). We then select a sample of 204 M\&A deals between ASX-listed firms that are completed during the financial years 2000 to 2007, to investigate the extent to which theories (traditional or managerial power) can explain the most variation in CEO compensation. We find that the traditional view and managerial approach are not mutually exclusive and they both have some impact on CEO compensation following merger completion. It is observed that board size is a dominant factor in setting CEO pay, suggesting that bigger boards pay higher CEO compensation in the year of M\&A completion. While the finding of board size is consistent with the rent extraction hypothesis, the negative relationship between measures of managerial power (CEO Chair and CEO Nominating) and CEO compensation is opposite to its predictions. In fact, CEO bonuses and total compensation are significantly lower if there is any entrenchment of the CEO in the governance process (e.g. CEO is also chair of the board, or is a member of the nominating committee). This

\footnotetext{
${ }^{4}$ This is the longest examining period in any Australian study on executive compensation so far. For example, Izan et al. (1998)'s study consists of 6 years from 1987 to 1992, Chalmers et al. (2006) use 4 years from 1999 to 2002, others (e.g. Coulton and Taylor (2002), Fleming and Stellios (2002)) adopt only single-year analyses.

${ }^{5}$ Boardroom Connect 4 database has remuneration data since 2000, however, in some years, particularly 2003 , there is a lot of missing observations; the name of companies and executives are there but without remuneration figures. Therefore, we have to manually extract their detailed pay data from annual reports. In addition, corporate governance data of each acquiring firm are also hand collected from company annual reports.
} 
result is in sharp contrast to the US evidence (Gristein and Hribar (2004)) where CEO power is a significant driver of CEO post-bid compensation.

With the exception of the cumulative return around the announcement date, we find more evidence that supports the traditional view. It is found that CEO compensation in acquiring firms is largely affected by accounting performance $(R O A)$ and stock market performance $(T S R)$. In addition, CEOs receive more cash bonuses if the deal is completed rather than being withdrawn, and the size of the deal significantly determines CEO salary and total compensation. Overall, our findings offer more support for the incentive alignment rather than the managerial approach approach with respect to $\mathrm{CEO}$ compensation following mergers.

The remainder of this paper is structured as follows. Section 2 reviews the literature on the link between M\&As and executive compensation, and provides hypotheses for the study. The regression models and variables are discussed in Section 3, while Section 4 illustrates the data sampling process. The empirical results are presented and discussed in Section 5. Finally, Section 6 provides some concluding remarks to the study.

\section{Literature Review and Hypothesis Development}

There are two competing views on the link between M\&As and CEO compensation. The traditional view, the incentive alignment perspective (or agency theory), argues that the board should offer the CEO a compensation package that maximises shareholder value (Jensen and Meckling (1976), Haugen and Senbet (1981)). Such compensation would discourage CEOs entering into value-destroying deals as argued in Jensen (1986)'s free cash flow theory of takeovers. The incentive alignment theory assumes that optimal compensation packages can mitigate agency problems (Jensen and Meckling (1976)). It also acknowledges that CEO compensation is a function of supply and demand for the CEO's skills, effort and performance. Opposing the traditional view is the managerial power approach (or rent extraction theory). As defined by Finkelstein (1992), managerial power is the ability of managers to influence or exert their will on the remuneration decisions made by the board of directors. Under this approach, managerial power creates the ability for management to obtain compensation packages that are sub-optimal and consequently reduce shareholder wealth (Core et al. (1999), Bebchuk et al. (2002)).

There is evidence in the literature that the traditional view is subject to the moral hazard 
problem. For example, Mirrlees (1976) and Grossman and Hart (1983) show that CEOs do not necessarily maximise shareholder wealth as their actions are unobservable to investors and they have incentives to maximise their personal benefits. Therefore, the board needs to design such a compensation package that aligns CEO incentives with observable measures that maximise value such as company stock returns or profitability ratios. McConnell and Servaes (1990) find empirical support for the relationship between executive remuneration and firm value (as measured by Tobin's q ratio). Australian studies find mixed results about the relationship between CEO compensation and firm performance. Previous research (e.g. Izan et al. (1998), Fleming and Stellios (2002)) find that CEO pay is not linked in any clear way to corporate performance, while a recent paper (Chalmers et al. (2006)) documents a positive pay-for-performance link.

Although executive compensation is set against a list of market factors, these factors are not strong enough to compel optimal contracting outcomes, and executives can still use their power to influence their compensation arrangements and to extract rents (Bebchuk and Fried (2003)). As argued in Bebchuk et al. (2002), a zero level of rent extraction is unlikely due to monitoring and incentives aligning devices being very costly. Bebchuk and Fried (2004), hence, contend that the managerial power hypothesis provides a more satisfying explanation of executive remuneration arrangements than the traditional view of optimal contracting. Under the managerial power approach, executive compensation will be higher for managers in corporations where managers have relatively more power.

The literature on executive compensation has further shown that CEOs in companies with weaker corporate governance often receive greater compensation than those in companies with stronger corporate governance (e.g. Core et al. (1999), Zhao and Lehn (2006)). There are a number of internal control mechanisms that can affect the CEO compensation level. Firstly, the entrenchment of the CEO in the governance process (e.g. the CEO is also chair of the board, or is a member of the nominating committee). Combining the dual role of CEO and chairman is equivalent to asking the CEO to self-evaluate, compromising the independence of the board. A separation of the two roles allows the board to exercise its control function more effectively (Jensen (1993)) and the separation is commonly associated with reduced managerial power (Brickley et al. (1997), Conyon and Peck (1998). However, Chalmers et al. (2006) do not find that the dual role of CEO and chairman is a significant effect on Australian CEO compensation. Contrary to the US evidence, they observe that CEO pay is lower when the CEO is also the chairman of the board, and this negative relationship is statistically significant in 
the case of shares-issued compensation. Besides duality, it is argued that the CEO presence on the nomination committee can also increase their ability to extract rents. Main et al. (1995) observe that the CEO has traditionally dominated the nomination process and they can have a greater ability to exert influence on the board than if the process is independent of the CEO. Shivdasani and Yermack (1999) document evidence on the ability of CEOs to affect the selection of directors. Core et al. (1999) report that the greater the level of power the CEO has over the selection of board members, the higher the level of compensation they receive.

Secondly, previous research has also found that independent directors act as monitors on behalf of shareholders, thus the ability of the CEO to exert influence over the board is positively related to the proportion of executive directors on the board. For instance, Rosenstein and Wyatt (1990) find that outside director appointments are related to significant positive share price reactions. Their results suggest that outsider-dominated boards, on average, improve company value by replacing ineffective management. Hallock (1997) reports that the existence of interlocking boards increases CEO pay, and more board diversity reduces CEO pay. Conyon and Peck (1998) conclude that top management pay and corporate performance are more aligned in companies with outsider-dominated boards. Paul (2005) documents that board independence reduces the likelihood of completing value-decreasing bids.

Finally, the size of the board of directors can significantly influence CEO pay. It is often believed that larger boards are less effective (Jensen (1993)). Yermack (1996) provides evidence that firm value and performance are a decreasing function of board size. Core et al. (1999) find that CEO is able to extract greater rents when corporate governance is weak, i.e. bigger board size. An Australian study by Chalmers et al. (2006) also documents similar findings in relation to the size of the board of directors. However, in contrast to US evidence (Core et al. (1999)) where rent extraction through $\mathrm{CEO}$ compensation is pervasive, economically significant and persistent, Chalmers et al. (2006) find that Australian CEOs are able to extract rent only from bonus and options compensation and the rent extraction does not persist beyond one year.

The literature on executive compensation following M\&As shows that CEOs of acquiring firms are, on average, rewarded with higher compensation for completing mergers. Most studies in the US and the UK give evidence in support of managerial power rather than value creation driving the payment of M\&A bonuses. For example, when examining the impact of M\&As on the remuneration of CEOs, both Gristein and Hribar (2004) and Coakley and Iliopoulou (2006) find that 
more powerful CEOs receive significantly larger post-acquisition bonuses. Datta et al. (2001) find a positive relationship between equity-based compensation of executives and company stock price performance following acquisitions. Girma et al. (2006) also notice that executive compensation is higher following mergers. Using the effect on returns around takeover announcement date as the benchmark, they document that CEOs of companies making value-enhancing acquisition receive significantly bigger cash pay than their counterparts with wealth-reducing acquisitions. Harford and Li (2007) show a detachment between CEO pay and company performance after acquisitions; CEOs of bidding firms are still better off despite the fact their shareholders are worse off. Malmendier and Tate (2008) observe that overconfident CEOs are more likely to overpay for target companies and undertake value-destroying mergers. In a recent UK study, Guest (2009) finds that CEOs are rewarded equally for bad and good acquisitions, and the acquiring firms' strength of corporate governance does not have a significant impact on CEO post-acquisition compensation.

Given these two different views of managerial compensation, the objective of this paper is to examine the extent to which managerial power and incentive alignment hypotheses are observed in the Australian market in the context of CEO compensation in the post-acquisition period. In particular, three research questions are addressed in this paper. Firstly, is CEO compensation affected by M\&A completion? Secondly, to what extent is CEO compensation received after the acquisition tied to value maximisation and CEO effort in completing the deal? Thirdly, does CEO power influence their compensation received following takeovers? It is expected that CEO compensation is higher following a successful M\&A completion, compared to CEO compensation prior to M\&A. Under the incentive alignment approach, there should be a positive relationship between the level of CEO compensation in acquiring firms and their skill, effort in completing the deal and the firm performance. On the contrary, the managerial power theory predicts that CEO bonuses and remuneration are positively related to the level of managerial power in the firm.

\section{Methodology}

\subsection{The relationship between CEO compensation and M\&As}

We first address the question of whether compensation and bonuses paid to CEOs are actually related to M\&A decisions. Following Gristein and Hribar (2004) and Coakley and Iliopoulou (2006), we estimate the following regression over the whole Boardroom Connect4 database in 
the period from 2000 to 2007 (the control sample).

$$
\begin{aligned}
& \text { Compensation }_{i t}=\alpha+\beta_{1} \text { Size }_{i(t-1)}+\beta_{2} R O A_{i t}+\beta_{3} R O A \text { Growth }_{i t}+\beta_{4} T S R_{i t} \\
& +\beta_{5} \text { SalesGrowth }_{i t}+\beta_{6} \text { Margin }_{i t}+\beta_{7} \text { MarginGrowt }_{i t} \\
& +\beta_{8} \text { AcquisitionDummyit }+\beta_{9} \text { AcquisitionDummy }{ }_{i(t-1)} \\
& +[\text { YearDummies }]+[\text { IndustryDummies }]+\epsilon_{i t}
\end{aligned}
$$

The dependent variable in equation (1) is the compensation paid to CEOs of acquiring firm $i$ at the end of year when merger is completed. We examine four types of compensation: bonus only, salary only, salary and bonus, and total compensation. Following the previous literature, the independent variables of equation (1) include:

- firm size measured as total book value of assets one year prior to the merger (Size).

- firm performance variables in the year of merger completion (ROA, ROA Growth, TSR, Sales Growth, Margin, Margin Growth). ${ }^{6}$.

- AcqusitionDummyt and AcqusitionDummyt-1 are binary variables set to equal 1 if the firm completed an acquisition during the year and one year before, respectively. If firms compensate their CEOs for acquisitions, the coefficients on both AcqusitionDummyt and AcqusitionDummyt-1 variables will be significantly positive.

- industry-specific ${ }^{7}$ and year-specific fixed effects to control for differences in compensation across industries and over time.

In their OLS regression analyses, both Gristein and Hribar (2004) and Coakley and Iliopoulou (2006) measure compensation figures in thousand of dollars and size in million of dollars. Since we have zero observations in some types of executive compensation, tobit regression is also performed in order to censor for these zero observations because OLS regression might suffer from mis-specification. Therefore, for the first three types of compensation (bonus only, salary only, salary and bonus), we analyse equation (1) using both OLS and tobit regressions with compensation and size variables are in dollars. For total compensation, since there are no zero observations, we use only OLS regression but size and compensation variables are expressed in both dollar value and natural logarithm figures.

\footnotetext{
${ }^{6}$ Description of each variable is in Table 1 in the Data section.

${ }^{7}$ Firms are sorted according to their 2-digit codes of Global Industry Classification System (GICS).
} 


\subsection{The influence of CEOs on their compensation received post-acquisition}

Our second and third research question are to examine the extent to which CEO effort, skill, performance and power can determine their level of compensation in the post-acquisition period. Therefore, the regression model of the sample of firms undertaking M\&As is estimated as follows (the treatment sample):

$$
\begin{aligned}
& \text { Compensation }_{i}=\chi+\delta_{1} \text { Size }_{i}+\delta_{2} \text { DealSize }_{i}+\delta_{3} \text { CompletionTime }_{i}+\delta_{4} \text { Diversify }_{i} \\
& +\delta_{5} \text { DealResult }_{i}+\delta_{6} C A R[-1,+1]_{i}+\delta_{7} \text { OfferPriceRevision } \text { fe }_{i}+\delta_{8} R O A_{i}
\end{aligned}
$$

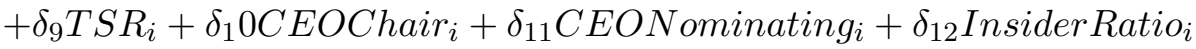

$$
\begin{aligned}
& +\delta_{13} \text { BoardSize }_{i}+[\text { YearDummies }]+[\text { IndustryDummies }]+\epsilon_{i}
\end{aligned}
$$

According to the traditional view, CEOs will be rewarded more if the deals require them to exert more effort and skill. The first set of variables in equation (2) is intended to measure managers' skill and effort exerted in M\&As. They include size of the deal (Deal Size), the time it takes to complete the deal (Completion Time), a proxy for diversified acquisitions (Diversify), the result of the deal (a dummy variable that equals to one if the deal is completed, not withdrawn), two-day abnormal returns (adjusted against the All Ordinaries Index) surrounding the announcement of the deal $(C A R[-1,1])$ to capture the market's reaction to the managerial decision, and a variable to indicate whether the final offer price has been revised from the original bid price (Offer Price Revision). Larger deals are more complex and require more effort and skill from managers, and similarly completed deals would require more managerial effort than withdrawn deals. Deals with a revision in offer price would demand more effort from CEOs of bidding firms than those without an offer price revision. It is also assumed that a longer the time to complete the deal is an indication that the CEO needed to exert additional effort. An acquisition of a company from a different industry would require less effort because of fewer integration problems between target and acquirer. Finally, a higher market's reaction to the deal announcement indicates that the acquisition is viewed positively by investors. Therefore, under the traditional approach, it would be expected that Deal Size, Completion Time, Deal Result, CAR[-1,1] and Offer Price Revision variables are all positively related to CEO compensation, while a negative relationship should exist between Diversify and CEO compensation.

The second set of variables in equation (2) is to measure company performance since it may be difficult for remuneration committees to quantify exactly the CEOs' effort and skill in takeover completion (Gristein and Hribar (2004)). We use return on assets (ROA) and stock return of 
the firm in the financial year $(T S R)$. It is expected that these accounting and stock market performance variables are positively related to the level of CEO compensation under the traditional view.

The third set of variables in equation (2) intends to capture managerial power and corporate governance of acquiring firms since Gristein and Hribar (2004) and Coakley and Iliopoulou (2006) find that CEO compensation is positively related to managerial power. Following the previous literature, we adopt a number of measures such as CEO Chair (a dummy variable that equals to one when the $\mathrm{CEO}$ also holds the position as chairman of the board of directors); CEO Nominating (a binary variable equal to one if the CEO is also a member of the nominating committee); Insider Ratio (the ratio of the number of executive directors on the board to total directors); and Board Size (the number of directors on the board). Under the managerial power approach, there should be a positive correlation between the level of managerial power in the firm and the level of executive compensation. In other words, the coefficients of all managerial power variables in equation (2) should be positive.

This paper also controls for ${ }^{8}$ industry, time fixed effects and size due to the impact of increasing bonuses over time and differences in company size and compensation across industries. For example, Murphy (1999) has found that CEOs in electric utilities earn significant lower levels of compensation than their counterparts in other industries, while CEOs in financial services companies earn higher pay. Also, managers may demand greater compensation for controlling organisations of greater corporate complexity, and because their own talents are relatively scare in some industries and market periods (Agarwal (1981)).

In our treatment sample, only the bonus component has zero observations. Therefore, bonus is analysed by using both the OLS and tobit regressions with dollar value for bonus, company

\footnotetext{
${ }^{8}$ In Gristein and Hribar (2004), the Heckman correction variable (Heckman (1979)) is calculated and included in the regression (2) in order to overcome the potential selection bias since acquiring firms are not randomly chosen from the population of firms. Following Gristein and Hribar (2004), we run a probit regression over the Boardroom Connect4 firms (total of 3,172 firms) over the period 2000 to 2007 for modelling the probability that a firm will undertake an acquisition. The explanatory variables in the probit regression are pre-merger market-tobook (M/B) ratio, cash to assets, debt to assets, ROA, operating revenue (log), and a dummy variable indicating whether the firm acquired another firm in the previous year. Industry-specific and year-specific fixed effects are also included. Significant variables at the $10 \%$ level from the probit regression consist of cash to assets, ROA, operating revenue and the acquisition dummy in the previous year. The estimates from the probit regression are used to construct the Heckman variable and then added into the regression (2). However, it is found in our sample that the Heckman variable, which is represented as the probability of firm undertaking an acquisition, is highly correlated with other variables in the regression (2). For example, its correlation coefficient is 0.39 with Size, 0.28 with Deal Size, 0.24 with ROA, -0.3 with Insider Ratio and 0.55 with Board Size. Therefore, we exclude the Heckman correction variable from the regression (2) due to the potential problem of multicollinearity.
} 
size and deal size variables (same measure as in Gristein and Hribar (2004)). For other types of compensation (i.e. salary only, salary and bonus, and total compensation), only the OLS regression is adopted and both dollar value and natural logarithm figures are used to measure the executive compensation, company size and deal size.

\section{Data}

\subsection{Sample}

Data on mergers and acquisitions are extracted from the SDC database. We only consider public companies (because of data availability) that have M\&A deals finalised during their financial years between 2000 and 2007. Deal-related information is obtained from SDC database, share prices are collected from the SIRCA Core Research Database, and other relevant accounting data come from Aspect FinAnalysis. CEO compensation data for each acquiring firm CEO are extracted from the Boardroom Connect4 database and their annual reports for the earlier years. Companies' annual financial reports are also manually checked for each acquiring firm's governance characteristics. The final treatment sample contains 204 M\&A deals. A definition of each variable together with its data source is presented in Table 1.

[Insert Table 1]

Our analysis also requires a control sample of firms (for the purpose of addressing research question one). We pick these firms on the basis that they must be publicly listed companies and must not have been involved in a merger and acquisition in the current financial year. Likewise, we also require remuneration, balance sheet and returns data for these firms; leaving a control sample of 4,002 observations. ${ }^{9}$

\subsection{Descriptive statistics of the treatment sample}

Table 2 presents summary statistics of acquiring firms in our treatment sample. ${ }^{10}$ Panel A of Table 2 shows the financial characteristics of firms one year before merger completion. Acquiring firms are, on average, quite large, approximately $\$ 6.7$ billion in total book assets and $\$ 2.4$ billion in market capitalisation. Smaller median figures (\$314 million and $\$ 398$ million, respectively) together with high standard deviation ( $\$ 35$ billion and $\$ 6.9$ billion, respectively) indicate that the distribution of firm size and market capitalisation are highly skewed. Acquiring firms in our

\footnotetext{
${ }^{9}$ The treatment sample of 204 observations is a subset in this control sample.

${ }^{10} \mathrm{We}$ do not present the summary statistics for the control sample.
} 
sample perform quite well with average return on assets of $6.32 \%$ and average stock return of $14 \%$.

[Insert Table 2]

Panel B of Table 2 describes the deal characteristics of firms in our treatment sample. The average deal size is around $\$ 320$ million, while the median figure is approximately $\$ 45$ million. It takes an average of 107 days from the date of deal announcement to complete, and only less than $75 \%$ of the firms complete the deal in 4 months (125 days). The majority of firms acquire other companies with the same 2-digit GICS industry code, only $19 \%$ of firms in our sample buy firms from different industries. The market reacts quite positively to the M\&A announcement, with $50 \%$ of the firms having positive cumulative abnormal return (CAR) of above $0.52 \%$ over three event windows: one day before the announcement $[-1,0]$, two days surrounding the announcement $[-1,1]$, and four days centred on the announcement date [-2,2]. In our sample, 37\% of the deals have an offer price revision after the announcement of the initial offer, and $77 \%$ of the deals are completed.

Corporate governance characteristics of acquiring firms in the year of M\&A completion are presented in Panel $\mathrm{C}$ of Table 2. In our sample, about $7.4 \%$ of the firms have CEOs who are also the chairperson of the board. This indicates the dual role of CEOs and chairmen in Australian companies is significantly lower than the US and UK counterparts, and they reasonably follow the recommendation of the ASX Corporate Governance Council. ${ }^{11}$ Studies by Gristein and Hribar (2004) and Coakley and Iliopoulou (2006) reveal that $73 \%$ of US CEOs are also chairmen while this figure is $24 \%$ for UK CEOs. In contrast, $69 \%$ of Australian CEOs are member of the nominating committee, the committee that proposes new board members, while this proportion is $48 \%$ in the UK study (Coakley and Iliopoulou (2006)) and 25\% in the US study (Gristein and Hribar (2004)). In addition, the average Australian board size is 7 directors which is smaller than both the US and the UK markets. The majority of Australian board members are nonexecutives, with the average board having approximately $30 \%$ of executive directors, which is similar to the US market.

Table 3 presents summary statistics for the compensation that CEOs received over three separate one-year periods: the year prior to the merger (pre-merger), the year of the merger completion,

\footnotetext{
${ }^{11}$ In 2003, the ASX Corporate Governance Council has published "Principles of good corporate governance and best practice recommendations" to ASX-listed companies. The Council has suggested in Recommendation 2.3 that "the roles of chairperson and CEO should not be exercised by the same individual".
} 
and one year after the merger is completed (post-merger). Figures are shown separately for four types of compensation: bonus, salary, salary and bonus, and total compensation. Compared with the year before a merger, Australian CEOs enjoy increases in their median bonus pay of $\$ 38,000$ in the acquisition completion year and of $\$ 47,000$ in the post-merger year. However, not all companies award cash bonuses to their CEOs for M\&A decisions, just over $25 \%$ of acquiring firms in our sample do not pay any bonus at all. The increase in pay following the completion of the deal is also observed in other forms of compensation. CEOs also benefit from additional salary of $\$ 78,000$ immediately following the deal being completed and $\$ 162,000$ in one year after that. Similar figures for extra total compensation are $\$ 120,000$ and $\$ 310,000$, respectively.

[Insert Table 3]

\section{Empirical Results}

\subsection{Is CEO compensation higher following M\&As?}

This section reports the results of tests relating to research question one: to examine the extent to which CEOs of acquiring firms are awarded higher compensation after completing M\&As. The model is estimated using equation (1) over the entire Boardroom Connect4 database for the period 2000-2007. The results are presented in Table 4 for four different types of compensation: bonus only, salary only, salary and bonus, and total compensation.

[Insert Table 4]

We first replicate Gristein and Hribar (2004)'s study by using OLS technique with size and compensation variables expressed in dollar value. The results are presented in Column (1), (3), (5) and (7) of Table 4. Consistent with the previous studies in the US and UK markets, the coefficients on both Acquisition dummies are positive and statistically significant at the $1 \%$ level. These results suggest that after controlling for size, acquiring firms not only pay higher CEO bonuses but also higher salary and total compensation for acquisitions in the year of completing the merger and one year after. Our results are slightly different to Gristein and Hribar (2004)'s findings in the US market in which they observe that the remuneration committees reward CEOs of acquiring firms mainly through bonuses. Similar to the prior Australian literature on CEO compensation, we also find significant positive effects on compensation for company size, return on assets and company stock return (e.g. Izan et al. (1998), Fleming and Stellios (2002), Chalmers et al. (2006)). 
We further extend Gristein and Hribar (2004)'s method by using a tobit regression for the first three types of compensation (bonus only, salary only, salary and bonus) since they contain observations with zero values. The results are very similar to the OLS results and are shown in Column (2), (4) and (6) of Table 4. It is evident that both Acquisition variables have positive and significant coefficients with larger coefficients when adopting the tobit regression.

For total compensation, we adopt the OLS technique only (since all observations are non-zero) and use two measures for the size and compensation variables: dollar value (same measurement as Gristein and Hribar (2004)) and natural logarithm. The results in Column (7) and (8) of Table 4 show that the coefficients on the Acquisition variables are indeed significantly positive.

In short, our analyses indicate that CEOs of acquiring firms are awarded higher bonuses and compensation for the completion of M\&As after controlling for company performance, company size and fixed effects. The next section will investigate which factors determine CEO compensation in the post-acquisition period.

\subsection{Determinants of CEO post-acquisition compensation}

This section investigates the second and third research questions: the extent to which the incentive alignment approach and the managerial power approach can explain the level of CEO compensation received after mergers. We first examine CEO bonuses by performing both OLS and tobit regressions ${ }^{12}$ and the results are presented in Table 5 and Table 6 , respectively. There are multiple specifications in each table: we consider only the set of variables that measure managerial skill and effort in completing the deal in the first specification (Column (1)). The second specification (Column (2)) uses variables that measure company accounting and stock market performance. The third specification (Column (3)) combines all variables measuring CEO effort, skill and firm performance, while the forth specification (Column (4)) only takes into account managerial power variables. In the last specification (Column (5)), we combine all variables in one equation to examine the relative effects of the two theories on CEO pay. All the regressions control for company size, year-specific and industry-specific fixed effects.

[Insert Table 5 and 6]

Table 5 and Table 6 show very similar results. The coefficient of the Size variable is signif-

\footnotetext{
${ }^{12}$ As mentioned in the Methodology section, OLS regression may suffer from mis-specification when the bonus variable is truncated at zero. Therefore, we place more weight on the results of tobit regresion.
} 
icantly positive across all specifications, suggesting that larger acquiring companies are more complex to manage and tend to pay higher bonuses to their CEOs. This positive association is consistent with previous Australian research on executive compensation (e.g. Izan et al. (1998), Fleming and Stellios (2002), Chalmers et al. (2006)). The Deal Result and Offer Price Revision variables are significantly positive in the tobit regression, indicating that managers are actually compensated for their effort in completing takeover deals. However, there is a significantly negative relationship between the two-day market-adjusted returns surrounding the announcement $(C A R[-1,1])$ and CEO bonuses. The $C A R[-1,1]$ variable reflects the market's perception on the quality of the acquisition decision, therefore, this contradicts with the traditional view. These findings further suggest that there is mixed evidence supporting the incentive alignment approach that managerial bonuses received following completion of the deal are linked to managerial effort and skill in the takeover deal.

As mentioned earlier in Section 2, in order to align CEO incentives to shareholders' benefits, the board also needs to take into account observable measures of the firm's profitability in designing the CEO remuneration package. We thus include two variables to measure company performance, return on assets $(R O A)$ and company annual stock performance $(T S R)$, in the analysis of CEO bonuses. Both performance variables are insignificant in the OLS regression (Table 5), while only ROA's coefficient is significantly positive in the tobit regression (Table 6) when the zero observations of bonuses are censored. The lack of association between CEO bonus and market performance is in line with previous empirical research in Australia (Fleming and Stellios (2002)). The significance of the ROA variable implies that bonuses paid to acquiring firm CEOs are related to the observable accounting measure of firm performance. This result is consistent with recent Australian research by Chalmers et al. (2006). ${ }^{13}$

The coefficient on the Board Size variable is positive and statistically significant at the $5 \%$ level (in the tobit regression). This result indicates that larger boards of directors pay higher CEO bonuses following takeovers, and possibly reflects monitoring difficulties with bigger boards (consistent with the rent extraction theory). It supports the findings of previous studies (e.g. Yermack (1996), Coakley and Iliopoulou (2006), Chalmers et al. (2006)) that smaller boards are an effective mechanism for internal corporate control. However, in contrast to the predictions of the managerial power hypothesis, the CEO Chair and CEO Nominating coefficients are negative

\footnotetext{
${ }^{13}$ We and Chalmers et al. (2006) both employ return on asset $(R O A)$ as a proxy for firm performance. However, earlier Australian studies (e.g. O'Neill and Iob (1999), Izan et al. (1998)) use other proxies such as return on equity and find no evidence to suggest a consistent trend of linking Australian executive pay and company performance.
} 
in both Table 5 and Table 6, and this negative relationship becomes statistically significant in the tobit regression (Table 6). These findings suggest that CEO bonuses after mergers are lower if the CEOs have more power. They are not in line with the US findings (Gristein and Hribar (2004)) that the increased bonus after acquisition is driven by CEO power. ${ }^{14}$

To further understand our findings in relation to the CEO Chair variable, we separate the original sample into 2 sub-samples: the first contains 15 observations in which the CEO is also the chairperson, and the second consists of 189 company years with no CEO duality. Descriptive statistics reveal that the first sub-sample always has lower average (and median) bonuses, and smaller size (measured as the book value of total assets in one year prior to acquisition) than that of the second sub-sample. For example, $50 \%$ of companies with CEO duality do not pay bonuses to their CEOs after mergers, while $50 \%$ of companies with no dual role of CEO and chairman give CEO bonuses of more than $\$ 100,000$; a large proportion $(87 \%)$ of companies in the first sub-sample have their total assets being less than $50 \%$ of companies in the second sub-sample. As firm size is positively related to CEO bonuses, it can be argued that those firms with a separation of CEO-Chairman positions are small firms and therefore their CEO should receive lower bonuses. To further explore this argument, we rank all firms in our original sample according to their size (book assets) and perform the analysis with a sample of 141 observations which contain the 15 companies having CEO duality. The regression result is very similar, CEOs of acquiring firms receive lower bonuses when they also hold the chairman position, and this result is robust when firm size is controlled for. ${ }^{15}$

Moreover, it is found that the negative relationship between bonuses and CEO duality is always significant when this correlation is examined conditionally on each of the other explanatory variables. In addition, the negative association between CEO duality (i.e. CEO is also the chairman) is also present in previous Australian research by Chalmers et al. (2006) when they examine the determinants of CEO compensation using the top 200 ASX-listed firms over the period from 1999 to 2002. In our sample of acquiring firms, the proportion of CEOs having a dual role is very small (approximately $7.4 \%$ on average), ${ }^{16}$ and it seems that the market would

\footnotetext{
${ }^{14}$ There are mixed findings in the UK market. In one of the earlier UK studies, Coakley and Iliopoulou (2006) reach similar conclusions as Gristein and Hribar (2004)'s study that CEO compensation following merger is driven more by CEO power when examining 73 completed M\&A deals for UK bidders over the period 1998-2001. However, in a recent UK study, Guest (2009) uses a more comprehensive sample of 4,528 acquisitions from 1984 to 2001 and documents no evidence that weak corporate governance can allow CEOs to extract higher rents through compensation in the post-bid period.

${ }^{15}$ The results of this analysis is available on request.

${ }^{16}$ In Chalmers et al. (2006)'s study, this proportion is $8.8 \%$.
} 
monitor powerful CEOs more closely, and as such bonuses on average are not increased following deal completion. Similar results are also obtained when we further analyse the CEO Nominating variable. Our findings, thus, do not support the managerial power approach, suggesting that the more power CEOs have, the less bonus they receive after acquisition.

In the next part of our analysis, we replace the dependent variable in equation (2) from bonuses to the other three forms of compensation: salary only, salary and bonus, and total compensation. In each component, we perform two types of OLS regression. ${ }^{17}$ The first one is referred to as \$'000 regression in which the compensation figure is in thousands of dollars, deal size and size variables are in million dollars (same measure as Gristein and Hribar (2004)). The second one is $L o g$ regression in which all compensation, size and deal size variables are expressed in natural logarithm. The results are presented in Table 7.

[Insert Table 7]

Overall, the results in Table 7 are very similar to that observed in Table 5 and Table 6. Company size (Size), return on assets (ROA), and the size of the board of directors (Board Size) are significantly positive across all three types of CEO compensation. CEO Chair and CEO Nominating variables are also negative and CEO Nominating variable becomes statistically significant under total compensation category. In addition, more variables that proxy for CEO's skill, effort and performance (Deal Size, Diversify, Offer Price Revision, company stock returns (TSR)) become statistically significant.

In summary, both the traditional view hypothesis and the rent extraction hypothesis do have certain explanatory power in determining $\mathrm{CEO}$ compensation following mergers. The positive association between the Board Size variable and all forms of CEO compensation does provide strong support for the argument that managerial power enables the extraction of rents by the CEO. However, in contrast to the predictions of the managerial power theory, the level of bonuses and total compensation are negatively related to the other two variables that proxy for managerial power (CEO Chair and CEO Nominating). Consistent with the traditional view, it is found that $\mathrm{CEO}$ compensation is determined by corporate accounting performance $(R O A)$ and stock market performance $(T S R)$. Total compensation is significantly associated with the higher stock market performance, while the other three components of CEO pay (bonus only, salary only, salary and bonus) are largely affected by company accounting profitability. In addition, CEOs

\footnotetext{
${ }^{17}$ Since all these types of compensation do not have zero observations, OLS regression is not subject to misspecification.
} 
receive more cash bonuses if the deal is completed rather than being withdrawn, and the size of the deal is a significant determinant of CEO salary and total compensation. Nevertheless, the significantly negative coefficient of $C A R[-1,1]$ when analysing the bonus component does not support for the hypothesis that CEOs are compensated for their effort in the M\&A deals. On the relative balance, it can be concluded that the higher level of Australian CEO bonuses and compensation after M\&As are driven more by CEO's effort, skill in completing the deal and corporate performance and less by managerial power.

\subsection{Robustness}

In our first robustness test, the $C A R[-1,1]$ variable to proxy for the deal performance is replaced by other variables to measure market-adjusted returns over various other event windows surrounding the announcement date: $C A R[-1,0], C A R[-2,2]$ and $C A R[-5,5]$. Additionally, we construct a scoring system of measuring CEO power, by taking the sum of the two binary managerial power variables (CEO Chair and CEO Nominating), which ranges from zero (least managerial power) to two (largest power). When equation (2) is analysed with the above variables, similar results are obtained.

If we put further restrictions on the sample of acquiring firms to exclude all multiple deals in any given year, and to exclude any company which undertakes M\&As in the previous year, our sample size is reduced to 119 company-year observations for the treatment sample, and 2,650 observations for the control sample. We repeat the regressions in equation $(1)^{18}$ and equation (2) with the new sample and still get the same results.

\section{Conclusion}

This paper uses a sample of 204 M\&A deals between ASX-listed companies from 2000 to 2007 to investigate the determinants of CEO pay following M\&A events. We find a significant association between executive compensation and M\&A deals, suggesting that acquiring firms reward their CEOs for the successful completion of M\&As. The higher level of CEO pay after mergers is found in all forms of compensation: bonus only, salary only, salary and bonus, and total compensation. It is also observed that larger firms demand higher quality CEOs and pay for such

\footnotetext{
${ }^{18}$ The equation (1) now does not have the variable AcquisitionDummyt-1 since we exclude all companies which have acquisitions in the previous year. It is found that the coefficient on AcquisitionDummyt variable is still significantly positive at the $1 \%$ level across all types of CEO compensation.
} 
quality. This paper finds that measures of effort, skill and performance, except for the cumulative return surrounding the announcement date, can explain CEO compensation in the year of completing acquisitions. In particular, company stock performance (TSR) and accounting performance $(R O A)$ are positively related to $\mathrm{CEO}$ compensation; CEOs are awarded higher cash bonuses for completed rather than withdrawn deals; larger deal size is correlated with higher CEO salary and total compensation.

With the exception of the Board Size variable, we do not find that the managerial power approach can explain much of the cross-sectional variation in CEO compensation. In fact, our empirical results indicate that CEOs of acquiring firms receive significantly lower bonuses and total compensation when they have more managerial power (i.e. the CEO is also the chair of the board, or the CEO also holds a seat on the nomination committee). These results are in line with previous Australian research on CEO compensation of companies listed on the Australian Stock Exchange (Chalmers et al. (2006)). Our findings, however, are in sharp contrast to the US market where rent extraction through CEO compensation following M\&A deals is economically significant (Gristein and Hribar (2004)). The reason is probably due to the fact that the entrenchment of the CEO in corporate governance is more severe in the US market with $73 \%$ of US firms having CEOs being also the chairman of the board (Gristein and Hribar (2004)), while this figure in Australia is approximately 8\%. Overall our results favour the alignment incentive rather than the managerial power explanation in determining CEO compensation after mergers. 


\section{References}

Agarwal, N. C., 1981. Determinants of Executive Compensation. Industrial Relations 20 (1), $36-45$.

Bebchuk, L., Fried, J., 2004. Pay without Performance: The Unfulfilled Promise of Executive Compensation. Harvard University Press, MA.

Bebchuk, L. A., Fried, J. M., 2003. Executive Compensation as an Agency Problem. Journal of Economic Perspectives 17 (1), 71-92.

Bebchuk, L. A., Fried, J. M., Walker, D. I., 2002. Managerial Power and Rent Extraction in the Design of Executive Compensation. The University of Chicago Law Review 69, 751-846.

Brickley, J. A., Coles, J. L., Jarrell, G., 1997. Leadership Structure: Separating the CEO and Chairmand of the Board. Journal of Corporate Finance 3 (3), 189-220.

Chalmers, K., Koh, P., Stapledon, G., 2006. The Determinants of CEO Compensation: Rent Extraction or Labour Demand? The British Accounting Review 38, 259-275.

Coakley, J., Iliopoulou, S., 2006. Bidder CEO and Other Executive Compensation in UK M\&As. European Financial Management 12 (4), 609-631.

Conyon, M. J., Peck, S. I., 1998. Board Control, Remuneration Committees, and Top Management Compensation. The Academy of Management Journal 41 (2), 371-406.

Core, J. E., Holthausen, R. W., Larcker, D. F., 1999. Corporate Governance, CEO Compensation, and Firm Performance. Journal of Financial Economics 51 (3), 371-406.

Coulton, J., Taylor, S., 2002. Option Awards for Australian CEOs: The Who, What and Why. Australian Accounting Review 12 (1), 25-35.

Datta, S., Iskandar-Datta, M., Raman, K., 2001. Executive Compensation and Corporate Acquisition Decisions. Journal of Finance 56 (6), 2299-2336.

Finkelstein, S., 1992. Power in Top Management Team: Dimension, Measurement and Validation. The Academy of Management Journal 35 (3), 505-538.

Fleming, G., Stellios, G., 2002. CEO Compensation, Managerial Agency and Boards of Directors in Australia. Accounting Research Journal 15 (2), 126-145.

Girma, S., Thompson, S., Wright, P. W., 2006. The Impact of Merger Activity on Executive Pay in the United Kingdom. Economica 73 (290), 321-339.

Gristein, Y., Hribar, P., 2004. CEO Compensation and Incentives: Evidence from M\&A Bonuses. Journal of Financial Economics 73 (1), 1190143.

Grossman, S., Hart, O., 1983. An Analysis of the Principal Agent Problem. Econometrica 51 (1), $7-45$.

Guest, P. M., 2009. The Impact of Mergers and Acquisitions on Executive Pay in the United Kingdom. Economica 76 (301), 149-175.

Hallock, K. F., 1997. Reciprocally Interlocking Boards of Directors and Executive Compensation. Journal of Financial and Quantitative Analysis 32 (3), 331-334.

Harford, J., Li, K., 2007. Decoupling CEO Wealth and Firm Performance: The Case of Acquiring Firm CEOs. Journal of Finance 62 (2), 917-949. 
Haugen, R. A., Senbet, L. W., 1981. Resolving the Agency Problems of External Capital through Option. Journal of Finance 36 (3), 629-647.

Heckman, J. J., 1979. Sample Selection Bias as a Specification Error. Econometrica 47 (1), $153-161$.

Izan, H. Y., Sidhu, B., Taylor, S., 1998. Does CEO Pay Reflect Performance? Some Australian Evidence. Corporate Governance: An International Review 6 (1), 39-47.

Jensen, M., 1986. Agency Costs of Free Cash Flow, Corporate Finance and Takeovers. American Economic Review 76, 323-329.

Jensen, M. C., 1993. The Modern Industrial Revolution, Exit and the Failure of Internal Control Systems. Journal of Finance 48 (3), 831-880.

Jensen, M. C., Meckling, W. H., 1976. Theory of the Firm: Managerial Behaviour, Agency Costs and Ownership Structure. Journal of Financial Economics 3 (4), 305-360.

Main, B. G. M., III, C. A. O., Wade, J., 1995. The CEO, the Board of Directors and Executive Compensation: Economic and Psychological Perspectives. Industrial and Corporate Change $4(2), 293-332$.

Malmendier, U., Tate, G., 2008. Who Makes Acquisitions? CEO Overconfidence and the Market's Reaction. Journal of Financial Economics 89 (1), 20-43.

McConnell, J. J., Servaes, H., 1990. Additional Evidence on Equity Ownership and Corporate Value. Journal of Financial Economics 27, 595-612.

Mirrlees, J., 1976. The Optimal Structure of Incentives and Authority within an Organisation. Bell Journal of Economics 7, 105-131.

Murphy, K. J., 1999. Executive Compensation, University of Southern California Working Paper. Available at SSRN: http://ssrn.com/abstract $=163914$.

O’Neill, G. L., Iob, M., 1999. Determinants of Executive Remuneration in Australian Organisation: An Exploratory Study. Asia-Pacific Journal of Human Resources 37 (1), 65-75.

Paul, D. L., 2005. Board Composition and Corrective Action: Evidence from Corporate Responses to Bad Acquisition Bids, Washington State University Working Paper. Available at SSRN: http://ssrn.com/abstract $=274574$.

Rosenstein, S., Wyatt, J. G., 1990. Outside Directors, Board Independence, and Shareholder Wealth. Journal of Financial Economics 26 (2), 175-191.

Shivdasani, A., Yermack, D., 1999. CEO Involvement in the Selection of New Board Members: An Empirical Analysis. Journal of Finance 54, 1829-1853.

Yermack, D., 1996. Higher Market Valuation of Companies with a Small Board of Directors. Journal of Financial Economics 40 (1), 185-211.

Zhao, Lehn, 2006. CEO Turnover after Acquisitions: Are Bad Bidders Fired? Journal of Finance 61 (4), 1759-1811. 
Table 1: Definition of all dependent and independent variables

\begin{tabular}{|c|c|c|}
\hline Variables & Definition & $\begin{array}{l}\text { Sources } \\
\text { of data }\end{array}$ \\
\hline \multicolumn{3}{|c|}{ CEO compensation of acquiring firms } \\
\hline Total compensation & $\begin{array}{l}\text { The sum of salary, director's fee, bonus, superannuation, } \\
\text { allowances, non-cash, motor, committee fees, consulting fees, } \\
\text { retire/termination, other, long-term incentive plan (LTIP), } \\
\text { accrued entitlements, stock options and shares }\end{array}$ & $\begin{array}{l}\text { Boardroom and } \\
\text { annual reports }\end{array}$ \\
\hline Salary & The sum of salary, director's fees and superannuation & $\begin{array}{l}\text { Boardroom and } \\
\text { annual reports }\end{array}$ \\
\hline Bonus & Bonus paid to CEO & $\begin{array}{l}\text { Boardroom and } \\
\text { annual reports }\end{array}$ \\
\hline Salary E Bonus & The sum of salary, director's fee, superannuation and bonus & $\begin{array}{l}\text { Boardroom and } \\
\text { annual reports }\end{array}$ \\
\hline
\end{tabular}

$\begin{array}{lll}\begin{array}{l}\text { Performance and characteristics of acquiring firms } \\ \text { Size }\end{array} & \begin{array}{l}\text { Book value of total assets of acquiring firm prior to the } \\ \text { merger and acquisition }\end{array} & \text { FinAnalysis } \\ \text { ROA } & \text { Earnings before tax divided by total assets } & \text { FinAnalysis } \\ \text { ROA Growth } & \text { Current ROA divided by ROA in the previous year } & \text { FinAnalysis } \\ \text { TSR } & \text { The raw return of acquiring firm's shares during the } & \text { FinAnalysis } \\ & \text { financial year of merger completion } & \\ \text { Sales Growth } & \text { Sales in current year divided by sales in the previous year } & \text { FinAnalysis } \\ \text { Margin } & \text { Earnings before tax divided by sales } & \text { FinAnalysis } \\ \text { Margin Growth } & \text { Margin in the current year divided by margin in the previous year } & \text { FinAnalysis }\end{array}$

\section{Deal characteristics}

Deal Size
Completion Time

The dollar value of the deal $\quad$ SDC

Completion Time The number of days between the deal announcement SDC

CAR[-1,1] The two-day market adjusted return (against All Ordinaries $\quad$ CRD

Diversify A binary variable coded as one if the 2-digit GICS industry codes FinAnalysis of acquirer and target firms are different, zero otherwise

Deal Result $\quad$ A binary variable coded as one if the deal is completed,

SDC zero otherwise

$\begin{array}{lll}\begin{array}{ll}\text { Governance characteristics of acquiring firms } \\ \text { CEO Chair }\end{array} & \begin{array}{l}\text { A binary variable coded as one if the CEO is also the } \\ \text { chairman of the board, zero otherwise }\end{array} & \text { Annual reports } \\ \text { AEO Nominating } & \begin{array}{l}\text { A binary variable coded as one if the CEO is on the } \\ \text { nominating committee, zero otherwise } \\ \text { remuneration committee, zero otherwise }\end{array} & \text { Annual reports } \\ \text { Board Size } & \begin{array}{l}\text { The number of members on the Board of Directors } \\ \text { Insider Ratio }\end{array} & \text { The percentage of executive directors on the Board }\end{array}$


Table 2: Descriptive statistics of acquiring firms

This table presents summary statistics of acquiring firms that completed their takeovers bids during the financial years from 2000 to 2007. The sample includes 204 deals between companies listed on the Australian Stock Exchange. Size is the book value of total assets one financial year prior to the merger; Market cap. is the acquirers' market value of equity a year before merger; $R O A$ is earnings before tax divided by the book value of total assets for the year prior to the merger. $T S R$ is the $\log$ of stock returns of acquiring firms for the financial year before the merger. Deal Size is dollar value of the deal. Completion Time is the number of days between the deal announcement and the day of completion; $C A R[-1,0], C A R[-1,1], C A R[-2,2], C A R[-5,5]$ indicate market adjusted returns (against the All Ordinaries Index) over the windows centred on the announcement day; Diversify is a binary variable coded one if the 2-digit GICS industry codes of acquirer and target firms are different, and zero otherwise. CEO Chair is a binary variable coded one if the CEO is also the chairman of the board; CEO Nominating is a binary variable coded one if the CEO is on the nominating committee; $C E O$ Remuneration is a binary variable coded one if the CEO is on the remuneration committee; Board Size is the number of members on the Board of Directors; Insider Ratio is the percentage of executive directors on the Board.

\begin{tabular}{|c|c|c|c|c|c|}
\hline & Mean & $\begin{array}{c}\text { Standard } \\
\text { Deviation }\end{array}$ & $\begin{array}{c}\text { 1st } \\
\text { Quartile }\end{array}$ & Median & $\begin{array}{c}\text { 3rd } \\
\text { Quartile }\end{array}$ \\
\hline \multicolumn{6}{|c|}{ Panel A: Financial characteristics of acquiring firms one year prior to M\&A completion } \\
\hline Size $(\$ \mathrm{~m})$ & 6,732 & 35,085 & 74.94 & 314.05 & 2,270 \\
\hline Market cap. $(\$ \mathrm{~m})$ & 2,354 & 6,948 & 75.56 & 397.85 & 2,127 \\
\hline$R O A$ & $6.32 \%$ & $16.59 \%$ & $1.56 \%$ & $6.21 \%$ & $11.41 \%$ \\
\hline$T S R$ & $14.00 \%$ & $55.53 \%$ & $-5.97 \%$ & $17.69 \%$ & $39.33 \%$ \\
\hline \multicolumn{6}{|c|}{ Panel B: Deal characteristics } \\
\hline Deal Size $(\$ \mathrm{~m})$ & 320.04 & 894.42 & 12.13 & 44.64 & 147.81 \\
\hline Completion Time (days) & 107 & 62 & 67 & 94 & 125 \\
\hline$C A R[-1,0]$ & $0.80 \%$ & $5.99 \%$ & $-1.14 \%$ & $0.52 \%$ & $2.56 \%$ \\
\hline$C A R[-1,1]$ & $1.18 \%$ & $6.99 \%$ & $-2.07 \%$ & $0.88 \%$ & $3.37 \%$ \\
\hline$C A R[-2,2]$ & $0.72 \%$ & $7.47 \%$ & $-2.57 \%$ & $0.82 \%$ & $3.81 \%$ \\
\hline Diversify & $18.63 \%$ & & & & \\
\hline Completed Deals & $76.96 \%$ & & & & \\
\hline Offer Price Revision & $36.76 \%$ & & & & \\
\hline \multicolumn{6}{|c|}{ Panel C: Governance characteristics of acquiring firms in M\&A completion year } \\
\hline CEO Chair & $7.35 \%$ & & & & \\
\hline CEO Nominating & $69.12 \%$ & & & & \\
\hline Board Size & 7 & 2 & 5 & 7 & 8 \\
\hline Insider Ratio & $28.29 \%$ & $15.10 \%$ & $16.35 \%$ & $25.00 \%$ & $40.00 \%$ \\
\hline
\end{tabular}


Table 3: CEO compensation statistics

This table presents summary statistics of compensation for CEOs of acquiring firms that completed their takeovers bids during the financial years from 2000 to 2007. The sample includes 204 deals between companies listed on the Australian Stock Exchange. All compensation figures are in thousand of dollars, and sourced from the Boardroom Connect4 database or manually collected from companies' annual reports. pre-merger indicates compensation figures in the financial year prior to the takeover, merger completion refers to compensation figures in the financial year when the deal is completed, and post-merger implies compensation figures in the financial year after the deal completion.

\begin{tabular}{|c|c|c|c|c|c|}
\hline & Mean & $\begin{array}{l}\text { Standard } \\
\text { Deviation }\end{array}$ & $\begin{array}{c}1 \text { st } \\
\text { Quartile }\end{array}$ & Median & $\begin{array}{c}\text { 3rd } \\
\text { Quartile }\end{array}$ \\
\hline \multicolumn{6}{|l|}{ Bonus } \\
\hline pre-merger & 252 & 446 & 0 & 34 & 253 \\
\hline merger completion & 393 & 1,269 & 0 & 72 & 363 \\
\hline post-merger & 508 & 1,793 & 0 & 81 & 400 \\
\hline \multicolumn{6}{|l|}{ Salary } \\
\hline pre-merger & 699 & 962 & 247 & 399 & 752 \\
\hline merger completion & 678 & 555 & 298 & 477 & 915 \\
\hline post-merger & 798 & 681 & 340 & 561 & 1,015 \\
\hline \multicolumn{6}{|l|}{ Salaryes Bonus } \\
\hline pre-merger & 952 & 1,231 & 275 & 498 & 1,076 \\
\hline merger completion & 1,071 & 1,482 & 324 & 623 & 1,265 \\
\hline post-merger & 1,306 & 2,104 & 369 & 733 & 1,548 \\
\hline \multicolumn{6}{|l|}{ Total compensation } \\
\hline pre-merger & 1,349 & 1,921 & 322 & 666 & 1,523 \\
\hline merger completion & 1,541 & 2,246 & 385 & 786 & 1,965 \\
\hline post-merger & 2,012 & 3,231 & 439 & 967 & 2,046 \\
\hline
\end{tabular}


Table 4: Regression of CEO compensation against firm performance, size and M\&A activity

The sample includes all ASX-listed firms in the Boardroom Connect4 database that have financial information over the year 2000 and 2007. Size is the book value of total assets one financial year prior to the merger; ROA is earnings before tax divided by the book value of total assets for the year prior to merger; ROA Growth is measured as current ROA divided by previous ROA; TSR is the log of stock returns of acquiring firms during the financial year of merger completion; Sales Growth equals current sales divided by sales in the previous year; Margin is earnings before tax divided by sales; Margin Growth is current margin divided by margin in the previous year; AcqusitionDummyt and AcqusitionDummyt-1 are binary variables equal to 1 if the firm completed an acquisition during the year and one year before, respectively. For regressions (1) through (7), the compensation figure is in thousands of dollars, and size is in millions of dollars (same measure as Gristein and Hribar (2004)). Regression (8) takes the natural logarithm of total compensation and size. Each regression uses White heteroskedasticity consistent covariance estimates. It also includes industry-specific and year-specific fixed effects to control for systematic differences in bonus across industries and over time. Figures in bracket are $t$-statistics (or $z$-statistics in case of tobit regressions). Emboldened figures indicate statistical significance of $10 \%$ level or better.

\begin{tabular}{|c|c|c|c|c|c|c|c|c|}
\hline & \multicolumn{2}{|c|}{$\begin{array}{l}\text { Bonus } \\
(\$ ' 000)\end{array}$} & \multicolumn{2}{|c|}{$\begin{array}{l}\text { Salary } \\
\left(\${ }^{\prime} 000\right)\end{array}$} & \multicolumn{2}{|c|}{$\begin{array}{c}\text { Salary \& Bonus } \\
(\$ ' 000)\end{array}$} & \multirow{2}{*}{\multicolumn{2}{|c|}{$\begin{array}{c}\text { Total compensation } \\
\text { OLS }\end{array}$}} \\
\hline & OLS & Tobit & OLS & Tobit & OLS & Tobit & & \\
\hline & & & & & & & $\$ \prime 000$ & $\log$ \\
\hline & $(1)$ & $(2)$ & $(3)$ & (4) & (5) & (6) & (7) & $(8)$ \\
\hline Size $_{t-1}$ & $\begin{array}{l}0.007 \\
{[4.94]}\end{array}$ & $\begin{array}{l}0.009 \\
{[5.03]}\end{array}$ & $\begin{array}{l}0.006 \\
{[5.6]}\end{array}$ & $\begin{array}{l}0.006 \\
{[5.61]}\end{array}$ & $\begin{array}{c}0.02 \\
{[6.08]}\end{array}$ & $\begin{array}{c}0.01 \\
{[6.09]}\end{array}$ & $\begin{array}{c}0.02 \\
{[6.28]}\end{array}$ & $\begin{array}{c}0.36 \\
{[60.91]}\end{array}$ \\
\hline$R O A_{t}$ & $\begin{array}{c}1.09 \\
{[2.57]}\end{array}$ & $\begin{array}{l}467.2 \\
{[3.02]}\end{array}$ & $\begin{array}{c}2.21 \\
{[2.02]}\end{array}$ & $\begin{array}{c}2.24 \\
{[2.02]}\end{array}$ & $\begin{array}{c}3.3 \\
{[2.34]}\end{array}$ & $\begin{array}{l}3.38 \\
{[2.31]}\end{array}$ & $\begin{array}{c}4.23 \\
{[2.16]}\end{array}$ & $\begin{array}{l}-0.004 \\
{[-1.90]}\end{array}$ \\
\hline ROAGrowth $h_{t}$ & $\begin{array}{l}-0.05 \\
{[-1.02]}\end{array}$ & $\begin{array}{l}-0.35 \\
{[-0.89]}\end{array}$ & $\begin{array}{l}-0.08 \\
{[-1.02]}\end{array}$ & $\begin{array}{l}-0.08 \\
{[-0.96]}\end{array}$ & $\begin{array}{l}-0.13 \\
{[-1.21]}\end{array}$ & $\begin{array}{l}-0.13 \\
{[-1.09]}\end{array}$ & $\begin{array}{l}-0.22 \\
{[-1.35]}\end{array}$ & $\begin{array}{l}-0.001 \\
{[-2.66]}\end{array}$ \\
\hline$T S R_{t}$ & $\begin{array}{l}23.45 \\
{[7.06]}\end{array}$ & $\begin{array}{l}123.7 \\
{[3.52]}\end{array}$ & $\begin{array}{c}7.58 \\
{[1.22]}\end{array}$ & $\begin{array}{c}8.38 \\
{[1.31]}\end{array}$ & $\begin{array}{l}31.03 \\
{[2.73]}\end{array}$ & $\begin{array}{c}32.88 \\
{[2.8]}\end{array}$ & $\begin{array}{l}55.51 \\
{[3.00]}\end{array}$ & $\begin{array}{c}0.08 \\
{[4.54]}\end{array}$ \\
\hline SalesGrowth $_{t}$ & $\begin{array}{c}-0.0003 \\
{[-1.96]}\end{array}$ & $\begin{array}{l}-0.007 \\
{[-1.34]}\end{array}$ & $\begin{array}{c}-0.0003 \\
{[-0.26]}\end{array}$ & $\begin{array}{c}-0.0002 \\
{[-0.24]}\end{array}$ & $\begin{array}{c}-0.0006 \\
{[-0.59]}\end{array}$ & $\begin{array}{c}-0.0005 \\
{[-0.56]}\end{array}$ & $\begin{array}{c}-0.0009 \\
{[-0.68]}\end{array}$ & $\begin{array}{c}0 \\
{[0.99]}\end{array}$ \\
\hline Margin $_{t}$ & $\begin{array}{l}0.002 \\
{[3.02]}\end{array}$ & $\begin{array}{c}0.01 \\
{[0.81]}\end{array}$ & $\begin{array}{l}0.003 \\
{[1.52]}\end{array}$ & $\begin{array}{l}0.003 \\
{[1.49]}\end{array}$ & $\begin{array}{l}0.005 \\
{[2.03]}\end{array}$ & $\begin{array}{l}0.005 \\
{[1.96]}\end{array}$ & $\begin{array}{l}0.005 \\
{[1.45]}\end{array}$ & $\begin{array}{c}0 \\
{[-2.22]}\end{array}$ \\
\hline MarginGrowtht & $\begin{array}{l}-0.002 \\
{[-1.92]}\end{array}$ & $\begin{array}{l}-0.01 \\
{[-0.67]}\end{array}$ & $\begin{array}{c}-0.004 \\
{[-1.3]}\end{array}$ & $\begin{array}{l}-0.005 \\
{[-1.45]}\end{array}$ & $\begin{array}{l}-0.006 \\
{[-1.58]}\end{array}$ & $\begin{array}{c}-0.009 \\
{[-1.5]}\end{array}$ & $\begin{array}{c}-0.01 \\
{[-1.88]}\end{array}$ & $\begin{array}{c}0 \\
{[0.001]}\end{array}$ \\
\hline AcquisitionDummyt & $\begin{array}{c}225.79 \\
{[2.67]}\end{array}$ & $\begin{array}{c}505.74 \\
{[3.71]}\end{array}$ & $\begin{array}{c}239.94 \\
{[6.1]}\end{array}$ & $\begin{array}{c}244.87 \\
{[6.25]}\end{array}$ & $\begin{array}{c}465.74 \\
{[4.74]}\end{array}$ & $\begin{array}{c}475.23 \\
{[4.83]}\end{array}$ & $\begin{array}{c}673.04 \\
{[4.64]}\end{array}$ & $\begin{array}{c}0.16 \\
{[3.40]}\end{array}$ \\
\hline AcqusitionDummyt-1 & $\begin{array}{c}57.6 \\
{[2.66]}\end{array}$ & $\begin{array}{c}238.29 \\
{[5.86]}\end{array}$ & $\begin{array}{c}114.71 \\
{[6.32]}\end{array}$ & $\begin{array}{l}114.7 \\
{[6.26]}\end{array}$ & $\begin{array}{c}172.32 \\
{[5.11]}\end{array}$ & $\begin{array}{c}172.31 \\
{[5.07]}\end{array}$ & $\begin{array}{c}250.41 \\
{[4.46]}\end{array}$ & $\begin{array}{l}0.08 \\
{[2.89]}\end{array}$ \\
\hline $\begin{array}{l}\text { Include fixed effects? } \\
\text { (Industry \& Year) }\end{array}$ & Yes & Yes & Yes & Yes & Yes & Yes & Yes & Yes \\
\hline Adjusted $R^{2}$ & $8.74 \%$ & & $12.50 \%$ & & $13.58 \%$ & & $14.00 \%$ & $52.87 \%$ \\
\hline No. of zero obs & & 2,854 & & 79 & & 72 & & \\
\hline No. of non-zero obs & & 1,352 & & 4,127 & & 4,134 & & \\
\hline Total obs & 4,206 & 4,206 & 4,206 & 4,206 & 4,206 & 4,206 & 4,206 & 4,206 \\
\hline
\end{tabular}


Table 5: Regression of CEO bonus against firm performance, managerial effort, skill and power - OLS regression

This table presents the results of an OLS regression of CEO bonuses on firm performance, managerial effort, skill and power. The sample includes all ASX-listed firms in the Boardroom Connect4 database that have financial information over the year 2000 and 2007. Bonuses are in thousands of dollars and size is in millions of dollars (same measure as Gristein and Hribar (2004)). Each regression uses White heteroskedasticity consistent covariance estimates. It also includes industry-specific and year-specific fixed effects to control for systematic differences in bonuses across industries and over time. Size is the book value of total assets one financial year prior to the merger; Deal Size is the dollar value of the deal; Completion Time is the log of the number of days between the date of deal announcement and the date of completion; Diversify is a binary variable coded one if the 2-digit GICS industry codes of acquirer and target firms are different, and zero otherwise; Deal Result is a binary variable coded one if the deal is completed and zero otherwise; $C A R[-1,1]$ indicates the market adjusted returns (against the All Ordinaries Index) over the windows centred on the announcement day; $R O A$ is earnings before tax divided by the book value of total assets; Offer Price Revision is a binary variable coded as one if the bidder revises the price offered to the target;Return is the log of stock returns of acquiring firms one financial year before the merger; $C E O$ Chair is a binary variable coded one if the CEO is also the chairman of the board; CEO Nominating is a binary variable coded as one if the CEO is on the nominating committee; Board Size is the number of members on the Board of Directors; Insider Ratio is the percentage of executive directors on the Board. Figures in bracket are $t$-statistics. Emboldened figures indicate statistical significance of $10 \%$ level or better.

\begin{tabular}{|c|c|c|c|c|c|}
\hline & \multicolumn{5}{|c|}{ Dependent variable: Bonus ( $\$ 000)$ - OLS regression } \\
\hline & $(1)$ & $(2)$ & $(3)$ & $(4)$ & (5) \\
\hline Size $_{t-1}$ & $\begin{array}{l}0.008 \\
{[2.77]}\end{array}$ & $\begin{array}{l}0.008 \\
{[2.61]}\end{array}$ & $\begin{array}{l}0.008 \\
{[2.75]}\end{array}$ & $\begin{array}{l}0.007 \\
{[2.86]}\end{array}$ & $\begin{array}{l}0.006 \\
{[2.86]}\end{array}$ \\
\hline Deal Size & $\begin{array}{c}0.07 \\
{[0.59]}\end{array}$ & & $\begin{array}{c}0.07 \\
{[0.58]}\end{array}$ & & $\begin{array}{c}-0.02 \\
{[-0.10]}\end{array}$ \\
\hline Completion Time & $\begin{array}{l}-30.21 \\
{[-0.29]}\end{array}$ & & $\begin{array}{l}-30.06 \\
{[-0.29]}\end{array}$ & & $\begin{array}{l}-38.61 \\
{[-0.35]}\end{array}$ \\
\hline Diversify & $\begin{array}{l}607.52 \\
{[1.34]}\end{array}$ & & $\begin{array}{l}623.26 \\
{[1.36]}\end{array}$ & & $\begin{array}{l}496.30 \\
{[1.33]}\end{array}$ \\
\hline Deal Result & $\begin{array}{c}202.72 \\
{[1.81]}\end{array}$ & & $\begin{array}{c}215.35 \\
{[1.90]}\end{array}$ & & $\begin{array}{l}114.66 \\
{[1.04]}\end{array}$ \\
\hline$C A R[-1,1]$ & $\begin{array}{l}-3.06 \\
{[-0.54]}\end{array}$ & & $\begin{array}{l}-3.62 \\
{[-0.63]}\end{array}$ & & $\begin{array}{l}-14.57 \\
{[-1.76]}\end{array}$ \\
\hline Offer Price Revision & $\begin{array}{l}266.06 \\
{[1.21]}\end{array}$ & & $\begin{array}{c}270.53 \\
{[1.22]}\end{array}$ & & $\begin{array}{c}246.77 \\
{[1.16]}\end{array}$ \\
\hline$R O A_{t}$ & & $\begin{array}{l}24.03 \\
{[0.18]}\end{array}$ & $\begin{array}{c}209.57 \\
{[1.50]}\end{array}$ & & $\begin{array}{l}142.12 \\
{[0.99]}\end{array}$ \\
\hline$T S R_{t}$ & & $\begin{array}{l}68.48 \\
{[0.78]}\end{array}$ & $\begin{array}{l}49.52 \\
{[0.58]}\end{array}$ & & $\begin{array}{l}-11.26 \\
{[-0.13]}\end{array}$ \\
\hline CEO Chair & & & & $\begin{array}{c}-101.47 \\
{[-0.67]}\end{array}$ & $\begin{array}{c}-264.91 \\
{[-1.34]}\end{array}$ \\
\hline CEO Nominating & & & & $\begin{array}{c}-356.19 \\
{[-1.48]}\end{array}$ & $\begin{array}{r}-401.55 \\
{[-1.64]}\end{array}$ \\
\hline Insider Ratio & & & & $\begin{array}{l}653.54 \\
{[1.06]}\end{array}$ & $\begin{array}{l}605.85 \\
{[1.17]}\end{array}$ \\
\hline Board Size & & & & $\begin{array}{c}115.23 \\
{[2.11]}\end{array}$ & $\begin{array}{l}95.56 \\
{[1.56]}\end{array}$ \\
\hline $\begin{array}{l}\text { Include fixed effects? } \\
\text { (Industry \& Year) }\end{array}$ & Yes & Yes & Yes & Yes & Yes \\
\hline Adjusted $R^{2}$ & $11.70 \%$ & $9.16 \%$ & $10.96 \%$ & $14.68 \%$ & $14.35 \%$ \\
\hline Total observations & 204 & 204 & 204 & 204 & 204 \\
\hline
\end{tabular}


Table 6: Regression of CEO bonus against firm performance, managerial effort, skill and power - Tobit regression

This table presents the results of a tobit regression of CEO bonuses against firm performance, managerial effort, skill and power. The sample includes all ASX-listed firms in the Boardroom Connect4 database that have financial information over the years 2000 through 2007. Bonuses are in thousands of dollars and size is in millions of dollars (same measure as Gristein and Hribar (2004)). Each regression uses White heteroskedasticity consistent covariance estimates. It also includes industry-specific and year-specific fixed effects to control for systematic differences in bonuses across industries and over time. Size is the book value of total assets one financial year prior to the merger; Deal Size is the dollar value of the deal; Completion Time is the log of the number of days between the date of deal announcement and the date of completion; Diversify is a binary variable coded as one if the 2-digit GICS industry codes of acquirer and target firms are different, and zero otherwise; Deal Result is a binary variable coded as one if the deal is completed and zero otherwise; CAR [-1,1] indicates the market adjusted returns (against the All Ordinaries Index) over the windows centred on the announcement day; $R O A$ is earnings before tax divided by the book value of total assets; Offer Price Revision is a binary variable coded as one if the bidder revises the price offered to the target; Return is the log of stock returns of acquiring firms one financial year before the merger; $C E O$ Chair is a binary variable coded as one if the CEO is also the chairman of the board; $C E O$ Nominating is a binary variable coded as one if the CEO is on the nominating committee; Board Size is the number of members on the Board of Directors; Insider Ratio is the percentage of executive directors on the Board. Figures in bracket are $z$-statistics. Emboldened figures indicate statistical significance of $10 \%$ level or better.

Dependent variable: Bonus (\$’000) - Tobit regression

\begin{tabular}{|c|c|c|c|c|c|}
\hline & $(1)$ & $(2)$ & $(3)$ & $(4)$ & $(5)$ \\
\hline Size $_{t-1}$ & $\begin{array}{l}0.009 \\
{[2.84]}\end{array}$ & $\begin{array}{l}0.009 \\
{[2.62]}\end{array}$ & $\begin{array}{l}0.008 \\
{[2.85}\end{array}$ & $\begin{array}{l}0.007 \\
{[2.92]}\end{array}$ & $\begin{array}{l}0.006 \\
{[2.83]}\end{array}$ \\
\hline Deal Size & $\begin{array}{c}0.15 \\
{[1.10]}\end{array}$ & & $\begin{array}{c}0.15 \\
{[1.15]}\end{array}$ & & $\begin{array}{l}-0.04 \\
{[-0.21]}\end{array}$ \\
\hline Completion Time & $\begin{array}{l}-66.42 \\
{[-0.33]}\end{array}$ & & $\begin{array}{l}-86.79 \\
{[-0.45]}\end{array}$ & & $\begin{array}{c}-168.32 \\
{[-0.79]}\end{array}$ \\
\hline Diversify & $\begin{array}{l}467.18 \\
{[0.91]}\end{array}$ & & $\begin{array}{l}700.12 \\
{[1.19]}\end{array}$ & & $\begin{array}{l}498.15 \\
{[1.05]}\end{array}$ \\
\hline Deal Result & $\begin{array}{c}421.75 \\
{[1.69]}\end{array}$ & & $\begin{array}{c}670.13 \\
{[2.37]}\end{array}$ & & $\begin{array}{c}449.18 \\
{[1.78]}\end{array}$ \\
\hline$C A R[-1,1]$ & $\begin{array}{l}-21.49 \\
{[-1.47]}\end{array}$ & & $\begin{array}{l}-23.79 \\
{[-1.61]}\end{array}$ & & $\begin{array}{l}-54.96 \\
{[-2.20]}\end{array}$ \\
\hline Offer Price Revision & $\begin{array}{l}379.13 \\
{[1.22]}\end{array}$ & & $\begin{array}{l}417.96 \\
{[1.33]}\end{array}$ & & $\begin{array}{l}435.19 \\
{[1.47]}\end{array}$ \\
\hline$R O A_{t}$ & & $\begin{array}{c}2,699.50 \\
{[3.14]}\end{array}$ & $\begin{array}{c}3,566.92 \\
{[2.84]}\end{array}$ & & $\begin{array}{c}3,399.52 \\
{[2.95]}\end{array}$ \\
\hline$T S R_{t}$ & & $\begin{array}{l}288.87 \\
{[1.33]}\end{array}$ & $\begin{array}{l}265.74 \\
{[1.17]}\end{array}$ & & $\begin{array}{l}98.62 \\
{[0.50]}\end{array}$ \\
\hline CEO Chair & & & & $\begin{array}{c}-791.31 \\
{[-1.59]}\end{array}$ & $\begin{array}{c}-1,209.34 \\
{[-2.09]}\end{array}$ \\
\hline CEO Nominating & & & & $\begin{array}{c}-542.12 \\
{[-1.62]}\end{array}$ & $\begin{array}{c}-692.68 \\
{[-1.89]}\end{array}$ \\
\hline Insider Ratio & & & & $\begin{array}{l}417.25 \\
{[0.51]}\end{array}$ & $\begin{array}{l}553.71 \\
{[0.70]}\end{array}$ \\
\hline Board Size & & & & $\begin{array}{c}209.41 \\
{[2.34]}\end{array}$ & $\begin{array}{c}197.70 \\
{[1.96]}\end{array}$ \\
\hline $\begin{array}{c}\text { Include fixed effects? } \\
\text { (Industry \& Year) }\end{array}$ & Yes & Yes & Yes & Yes & Yes \\
\hline No. of zero observations & 85 & 85 & 85 & 85 & 85 \\
\hline No. of non-zero observations & 119 & 119 & 119 & 119 & 119 \\
\hline Total observations & 204 & 204 & 204 & 204 & 204 \\
\hline
\end{tabular}


Table 7: Regression of CEO compensation against firm performance, managerial effort, skill and power

This table presents the results of an OLS regression of CEO compensation against firm performance, managerial effort, skill and power. The sample includes all ASX-listed firms in the Boardroom Connect4 database that have financial information over the years 2000 through 2007. For \$'000 regressions, compensation figures are in thousands of dollars, deal size and size are in millions of dollars (same measure as Gristein and Hribar (2004)). For Log regressions, compensation, size and deal size are all expressed in the natural logarithm. Each regression uses White heteroskedasticity consistent covariance estimates. It also includes industry-specific and year-specific fixed effects to control for systematic differences in bonuses across industries and over time. Size is the book value of total assets one financial year prior to the merger; Deal Size is the dollar value of the deal; Completion Time is the log of the number of days between the date of deal announcement and the date of completion; Diversify is a binary variable coded as one if the 2-digit GICS industry codes of acquirer and target firms are different, and zero otherwise; Deal Result is a binary variable coded as one if the deal is completed and zero otherwise; $C A R[-1,1]$ indicates the market adjusted returns (against the All Ordinaries Index) over the windows centred on the announcement day; ROA is earnings before tax divided by the book value of total assets; Offer Price Revision is a binary variable coded as one if the bidder revises the price offered to the target; Return is the log of stock returns of acquiring firms in the financial year before the merger; CEO Chair is a binary variable coded as one if the CEO is also the chairman of the board; CEO Nominating is a binary variable coded one as if the CEO is on the nominating committee; Board Size is the number of members on the Board of Directors; Insider Ratio is the percentage of executive directors on the Board. Figures in bracket are $t$-statistics. Emboldened figures indicate statistical significance of $10 \%$ level or better.

\begin{tabular}{|c|c|c|c|c|c|c|}
\hline & \multicolumn{6}{|c|}{ OLS regression } \\
\hline & \multicolumn{2}{|c|}{ Salary } & \multicolumn{2}{|c|}{ Salary \& Bonus } & \multicolumn{2}{|c|}{ Total compensation } \\
\hline & $\$ ’ 000$ & $\log$ & $\$ \prime 000$ & $\log$ & $\$ ’ 000$ & $\log$ \\
\hline Size $_{t-1}$ & $\begin{array}{l}0.001 \\
{[1.66]}\end{array}$ & $\begin{array}{c}0.21 \\
{[9.31]}\end{array}$ & $\begin{array}{l}0.007 \\
{[2.95]}\end{array}$ & $\begin{array}{c}0.30 \\
{[11.49]}\end{array}$ & $\begin{array}{c}0.02 \\
{[5.32]}\end{array}$ & $\begin{array}{c}0.31 \\
{[11.54]}\end{array}$ \\
\hline Deal Size & $\begin{array}{c}0.17 \\
{[3.36]}\end{array}$ & $\begin{array}{c}0.07 \\
{[2.64]}\end{array}$ & $\begin{array}{c}0.15 \\
{[0.82]}\end{array}$ & $\begin{array}{c}0.02 \\
{[0.68]}\end{array}$ & $\begin{array}{c}0.16 \\
{[0.60]}\end{array}$ & $\begin{array}{c}0.03 \\
{[0.99]}\end{array}$ \\
\hline Completion Time & $\begin{array}{c}1.48 \\
{[0.02]}\end{array}$ & $\begin{array}{c}0.02 \\
{[0.37]}\end{array}$ & $\begin{array}{l}-37.13 \\
{[-0.27]}\end{array}$ & $\begin{array}{l}0.006 \\
{[0.08]}\end{array}$ & $\begin{array}{l}23.43 \\
{[0.12]}\end{array}$ & $\begin{array}{c}0.09 \\
{[1.16]}\end{array}$ \\
\hline Diversify & $\begin{array}{l}-47.22 \\
{[-0.49]}\end{array}$ & $\begin{array}{c}-0.14 \\
{[-1.54]}\end{array}$ & $\begin{array}{c}449.09 \\
{[1.17]}\end{array}$ & $\begin{array}{c}-0.07 \\
{[-0.59]}\end{array}$ & $\begin{array}{c}1,162.86 \\
{[2.14]}\end{array}$ & $\begin{array}{c}0.14 \\
{[1.14]}\end{array}$ \\
\hline Deal Result & $\begin{array}{l}36.93 \\
{[0.42]}\end{array}$ & $\begin{array}{c}0.001 \\
{[0.006]}\end{array}$ & $\begin{array}{l}151.59 \\
{[1.01]}\end{array}$ & $\begin{array}{c}0.04 \\
{[0.49]}\end{array}$ & $\begin{array}{l}88.33 \\
{[0.41]}\end{array}$ & $\begin{array}{c}0.04 \\
{[0.36]}\end{array}$ \\
\hline$C A R[-1,1]$ & $\begin{array}{c}1.58 \\
{[0.40]}\end{array}$ & $\begin{array}{l}0.004 \\
{[0.92]}\end{array}$ & $\begin{array}{l}-12.99 \\
{[-1.29]}\end{array}$ & $\begin{array}{l}-0.003 \\
{[-0.57]}\end{array}$ & $\begin{array}{c}-3.57 \\
{[-0.24]}\end{array}$ & $\begin{array}{c}0.001 \\
{[0.1]}\end{array}$ \\
\hline Offer Price Revision & $\begin{array}{c}147.49 \\
{[2.12]}\end{array}$ & $\begin{array}{c}0.11 \\
{[1.51]}\end{array}$ & $\begin{array}{c}394.26 \\
{[1.74]}\end{array}$ & $\begin{array}{c}0.19 \\
{[2.26]}\end{array}$ & $\begin{array}{c}700.77 \\
{[2.19]}\end{array}$ & $\begin{array}{c}0.22 \\
{[2.26]}\end{array}$ \\
\hline$R O A_{t}$ & $\begin{array}{c}291.09 \\
{[3.46]}\end{array}$ & $\begin{array}{c}0.08 \\
{[0.53]}\end{array}$ & $\begin{array}{c}433.21 \\
{[2.48]}\end{array}$ & $\begin{array}{c}0.18 \\
{[1.10]}\end{array}$ & $\begin{array}{c}577.18 \\
{[2.14]}\end{array}$ & $\begin{array}{c}0.19 \\
{[1.05]}\end{array}$ \\
\hline$T S R_{t}$ & $\begin{array}{l}-23.24 \\
{[-0.40]}\end{array}$ & $\begin{array}{c}0.04 \\
{[0.60]}\end{array}$ & $\begin{array}{l}-34.49 \\
{[-0.28]}\end{array}$ & $\begin{array}{c}0.05 \\
{[0.78]}\end{array}$ & $\begin{array}{l}130.26 \\
{[0.78]}\end{array}$ & $\begin{array}{c}0.18 \\
{[2.39]}\end{array}$ \\
\hline CEO Chair & $\begin{array}{l}-93.24 \\
{[-0.90]}\end{array}$ & $\begin{array}{c}-0.13 \\
{[-0.91]}\end{array}$ & $\begin{array}{c}-358.15 \\
{[-1.59]}\end{array}$ & $\begin{array}{l}-0.20 \\
{[-1.24]}\end{array}$ & $\begin{array}{c}-364.71 \\
{[-1.13]}\end{array}$ & $\begin{array}{l}-0.05 \\
{[-0.3]}\end{array}$ \\
\hline CEO Nominating & $\begin{array}{c}1.78 \\
{[0.02]}\end{array}$ & $\begin{array}{c}0.06 \\
{[0.83]}\end{array}$ & $\begin{array}{c}-399.73 \\
{[-1.46]}\end{array}$ & $\begin{array}{l}-0.05 \\
{[-0.57]}\end{array}$ & $\begin{array}{c}-816.82 \\
{[-2.06]}\end{array}$ & $\begin{array}{c}-0.17 \\
{[-1.63]}\end{array}$ \\
\hline Insider Ratio & $\begin{array}{c}-165.84 \\
{[-0.64]}\end{array}$ & $\begin{array}{c}0.03 \\
{[0.11]}\end{array}$ & $\begin{array}{c}440.01 \\
{[0.73]}\end{array}$ & $\begin{array}{c}0.17 \\
{[0.52]}\end{array}$ & $\begin{array}{l}743.04 \\
{[0.90]}\end{array}$ & $\begin{array}{c}0.11 \\
{[0.32]}\end{array}$ \\
\hline Board Size & $\begin{array}{l}78.03 \\
{[2.91]}\end{array}$ & $\begin{array}{c}0.03 \\
{[1.61]}\end{array}$ & $\begin{array}{c}173.59 \\
{[2.58]}\end{array}$ & $\begin{array}{c}0.04 \\
{[1.83]}\end{array}$ & $\begin{array}{c}240.98 \\
{[2.62]}\end{array}$ & $\begin{array}{c}0.05 \\
{[1.84]}\end{array}$ \\
\hline $\begin{array}{l}\text { Include fixed effects? } \\
\text { (Industry \& Year) }\end{array}$ & Yes & Yes & Yes & Yes & Yes & Yes \\
\hline Adjusted $R^{2}$ & $36.89 \%$ & $67.75 \%$ & $25.17 \%$ & $70.00 \%$ & $34.41 \%$ & $70.24 \%$ \\
\hline Total observations & 204 & 204 & 204 & 204 & 204 & 204 \\
\hline
\end{tabular}




\section{Nives Botica Redmayne, Fawzi Laswad}

New Zealand public sector audit fees and audit effort: the impact of IFRS adoption

146 Robert Brooks, William Dimovski, Hoa Nguyen

UNDERPRICING, RISK MANAGEMENT, HOT ISSUE AND CROWDING OUT EFFECTS:

EVIDENCE FROM THE AUSTRALIAN RESOURCES SECTOR INITIAL PUBLIC OFFERINGS

234 David A. Brown, Teemu Malmi, Prabhu Sivabalan, Chi-Ling Wu

Annual budgets, rolling forecasts and competitive strategy

87 Philip Brown, Emily Sargent

The Top 20 Shareholders

309 Philip Brown, Andrew Ferguson, Peter Lam

Choice between Alternative Routes to Go Public: Backdoor Listing versus IPO

138 Martin Bugeja, Raymond da Silva Rosa, Lien Duong, HY Izan

CEO Compensation from M\&As in Australia

85 Gary Burke, Paul Collier, Michelle Phang, Nava Subramaniam

Risk Management: Drivers, Methods and Consequences

\section{Geoffrey Burrows, Phillip Cobbin, Jane Hronsky}

A Fine Education but no "Bluestocking": Harriett Amies, pioneer female accounting professional

60 Fong C C Steve, Quaddus Mohammed

A Pseudo-Longitudinal Study of Intranet Use in Hong Kong Public Hospitals

58 Steven Cahan, David Emanuel, Elmar Venter

Disaggregation and earnings persistence: Evidence from South Africa

250 Steven Cahan, Jayne Godfrey, Jane Hamilton, Debra J eter

The Association between Client and Industry Investment Opportunities, Auditor

Industry Specialization, and Audit Fees

88 Daryll Cahill, Kaye Hilliar, Paul Myers, Louise Robinson

Educational quality is NOT protected by examination hurdles

239 Patsie-Ann Capper, Sue Malthus, Liz Rainsbury

The composition of New Zealand public sector audit committees

301 Peter Carey, Elizabeth Carson, Michael De Martinis, Xiao Shen

The Impact of Audit Firm Change and Audit Partner Rotation on Auditor-Provided NonAudit Services

\section{Elizabeth Carson, Carlin Dowling}

THE PRODUCTION OF AUDIT SERVICES: THE RELATIONSHIP BETWEEN AUDIT

SUPPORT SYSTEM DESIGN AND AUDIT PRICING

96 J enna Chaffey, Mary Low, Karen Van Peursem

Audit Education at Higher Education Levels: Perception of New Zealand Professionals

170 Keryn Chalmers, J ayne Godfrey, Barbara Lynch

Globalising Water Accounting: Lessons from the Globalisation of Financial Reporting

293 Gerald K. Chau, Patrick W. Leung

The Effects of Feedback and Self-Explanation on Tax Judgment Performance

\section{Jerry Chen}

Usefulness of Pro Forma Earnings Adjustment Mandated in IPO Prospectuses: Its Association with IPO Pricing, Future Financial Performance and Future Stock Returns 


\section{Announging the 2010 Aptint Bonference}

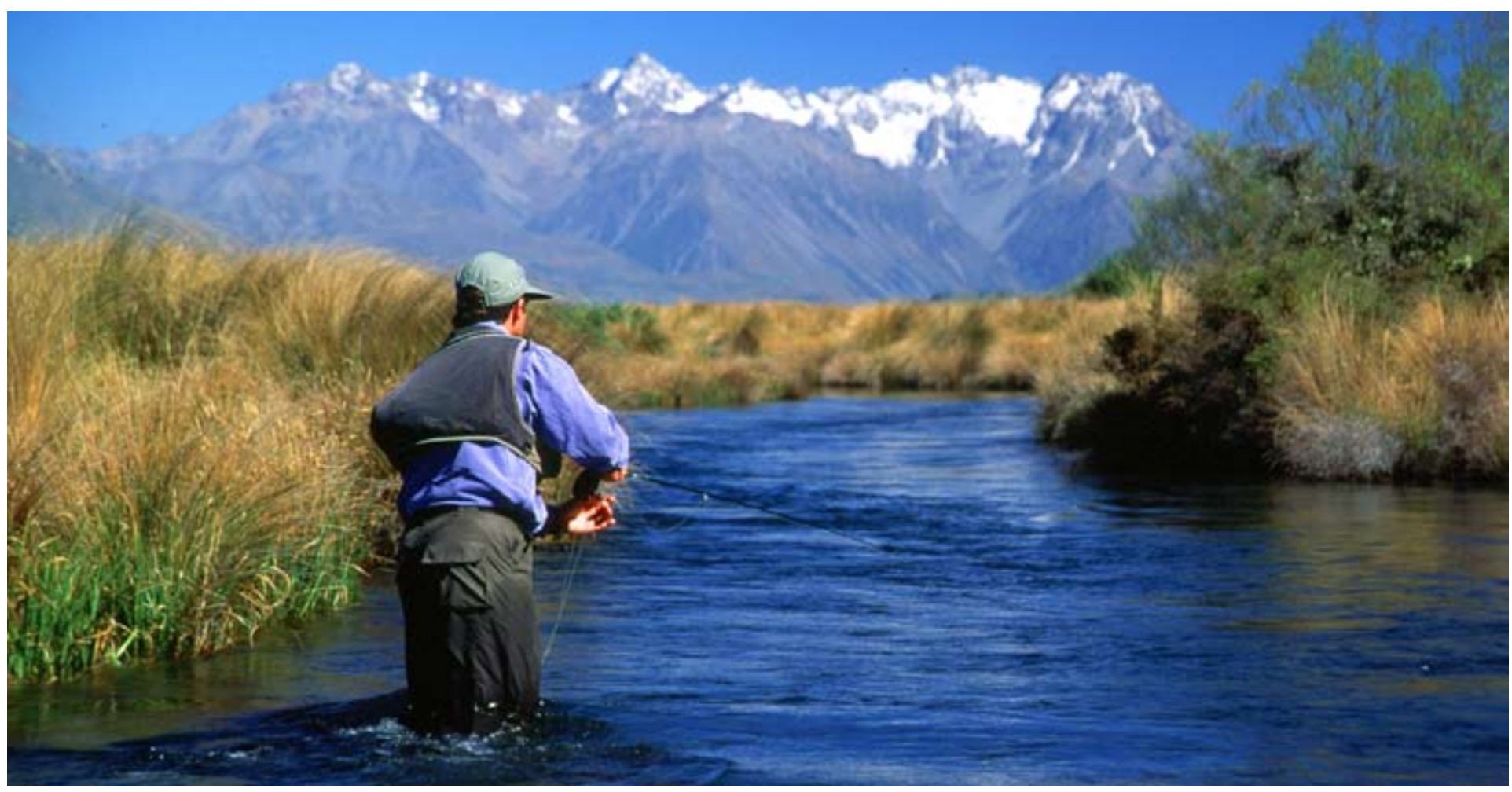

\section{Ghristchurch, New Zealand 4-6 July 2010}

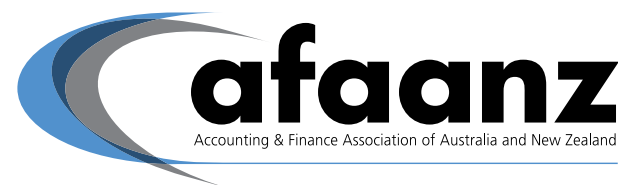

\section{Gall for papers}

This is the first call for papers for the 2010 AFAANZ Conference to be held in Christchurch, New Zealand. Papers are invited in the broad areas of accounting, finance, audit, corporate governance, accounting information systems, education, ethics, corporate social responsibility, tax and related topics. Papers should conform to the style and format of Accounting and Finance, the journal of AFAANZ. All papers will be subject to blind peer review so please ensure that there are no author details mentioned in your paper.

\section{Submission of Papers}

Further details regarding the submission of papers will be made available in the September 2009 issue of the AFAANZ Newsletter and on the AFAANZ website at http://www.afaanz.org/afaanz_conf.htm

\section{Submission Date}

Papers must be submitted by Monday, 15 February 2010. Late submissions will NOT be accepted under any circumstances so please allow adequate time to complete our online submission process. 